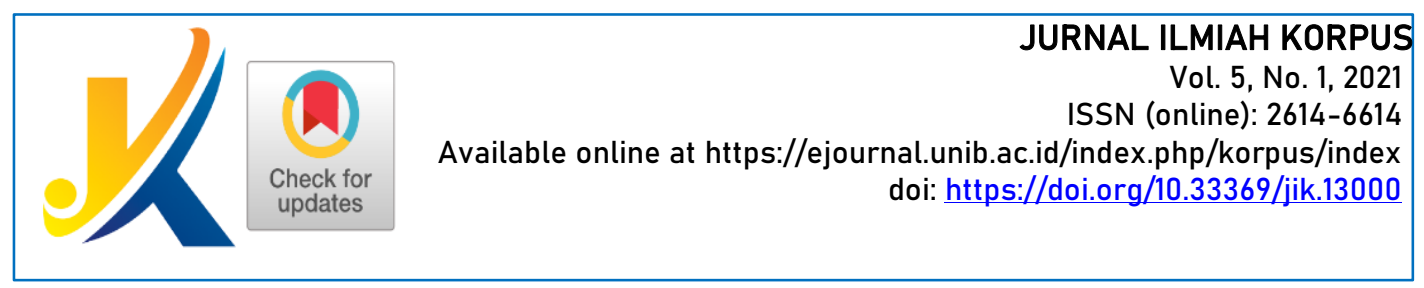

\title{
KEMAMPUAN MENULIS CERITA INSPIRATIF BERDASARKAN MEDIA VISUAL SISWA KELAS IX SMP NEGERI 4 KOTA BENGKULU
}

\author{
'Thossi Adios; ${ }^{2}$ Padi Utomo; ${ }^{3}$ Ria Ariesta \\ ${ }^{123}$ Program Studi Pendidikan Bahasa Indonesia Pendidikan Bahasa dan Seni \\ FKIP Universitas Bengkulu
}

\section{Abstrak}

\section{Korespondensi: thossiadios06@gmail.com}

Tujuan penelitian ini untuk mendeskripsikan kemampuan menulis cerita inspiratif berdasarkan media visual siswa kelas IX SMP Negeri 4 Kota Bengkulu. Penelitian ini menggunakan metode deskriptif kuantitatif yang dilaksanakan di SMP Negeri 4 Kota Bengkulu pada bulan Maret 2020. Populasi dalam penelitian ini semua siswa kelas IX SMP Negeri 4 Kota Bengkulu yang berjumlah 254 siswa. Sedangkan sampel dalam penelitian ini menggunakan teknik random sampling sebanyak $20 \%$ dari jumlah populasi berdasarkan teori persentase. Kemampuan menulis cerita inspiratif ini dinilai dari lima aspek, yaitu isi, struktur,diksi, kalimat, dan ejaan. Teknik pengumpulan data menggunakan teknik tes berupa penugasan kepada siswa untuk menulis cerita inspiratif berdasarkan media visual. Teknik analisis data dalam penelitian ini yaitu statistik deskriptif. Hasil penelitian dalam menulis cerita inspiratif berdasarkan media visual siswa kelas IX SMP Negeri 4 Kota Bengkulu dikategorikan cukup, sedangkan berdasarkan rumusan masalah secara khusus yang berupa kesesuaian isi dengan tema dikategorikan sangat baik, mengorganisasikan struktu dalam cerita inspiratif dikategorikan sangat baik, pengunaan diksi dikategorikan cukup, penggunaan kalimat dikategorikan cukup dan penggunaan ejaan pada cerita inspiratif dikategorikan cukup.

Kata Kunci: kemampuan menulis, cerita inspiratif, media visual

\section{Abstract}

The purpose of this study was to describe the ability to write inspirational stories based on visual media of class IX students of SMP Negeri 4 Bengkulu City. This study used a quantitative descriptive method which was conducted at SMP Negeri 4 Bengkulu City in March 2020. The population in this study were all students in grade IX SMP Negeri 4 Bengkulu City, amounting to 254 students. While the sample in this study used a random sampling technique of $20 \%$ of the population based on percentage theory. The ability to write inspirational stories is assessed from five aspects, namely content, structure, diction, sentences, and spelling. The data collection technique used a test technique in the form of assigning students to write inspirational stories based on visual media. The data analysis technique in this research is descriptive statistics. The results of the research in writing inspirational stories based on visual media of grade IX students at SMP Negeri 4 Bengkulu City were categorized as adequate, whereas based on the formulation of specific problems in the form of content conformity to the theme, they were categorized as very good, organizing structures in inspirational stories was categorized as very 
good, usage was categorized as sufficient, the use of sentences is categorized as adequate and the use of spelling in inspirational stories is categorized as adequate.

Keywords: writing skills, inspirational stories, visual media

\section{PENDAHULUAN}

Dalam pembelajaran banyak proses yang dilewati seseorang untuk mengembangkan potensi diri agar semua potensi yang dimiliki dapat dikembangkan dengan maksimal, karena dengan adanya pembelajaran peserta didik akan memperoleh pengetahuan yang luas, keterampilan yang kompleks serta sikap yang berkarakter. Selain itu, proses pembelajaran juga memberikan kemudahan yang diberikan pendidik kepada peserta didik agar dapat terjadi proses pemerolehan ilmu dan pengetahuan, penguasaan terhadap suatu pembelajaran, dalam proses pembelajaran juga akan membentukan sikap dan kepercayaan pada peserta didik yang nantinya akan menjadikan peserta didik mampu menguasai materi yang diajarkan dengan baik, dan tidak hanya itu dalam proses pembelajaran tidak hanya mentransfer ilmu tetapi juga dapat melihat atau mengkaitkan proses pembelajaran dengan kehidupan sehari-hari sehingga peserta didik mampu berfikir lebih luas dan mengkaitkan dengan kehidupan yang ada. Seperti pendapat Greenberg dan Baron (dalam Wibowo, 2016: 147) pembelajaran didefinisikan sebagai perubahan yang relatif permanen dalam prilaku yang terjadi sebgai hasil pengalaman.

Kegiatan menulis dapat menuangkan ide ke bentuk tulisan yang dapat dikaitkan dalam kehidupan. Menulis merupakan sebuah proses kreatif menuangkan gagasan dalam bentuk bahasa tulis dalam tujuan, misalnya memberitahu, meyakinkan, atau menghibur. Menurut Tarigan (dalam Dalman,2016: 4) mengemukakan bahwa menulis ialah menurunkan atau melukiskan lambang-lambang grafis yang menghasilkan suatu bahasa yang dipahami oleh seseorang sehingga orang lain dapat membaca lambang-lambang grafis tersebut dan dapat memahami bahasa dan grafis itu.

Banyak sekali faktor yang menghambat dalam proses menulis, salah satunya yaitu kurangnya pengetahuan, seringkali kita rasakan saat akan menulis suatu karya kita terhambat oleh kata-kata dan melihat kembali apakah kalimat yang kita tulis sudah sesuai atau belum. Pembelajaran di sekolah salah satu sarana dalam mengembangkan keterampilan menulis karena keberhasilan siswa mengikuti pelajaran di sekolah banyak ditentukan oleh keterampilan menulis. Oleh karena itu, keterampilan menulis menjadi sangat penting bagi semua mata pelajaran dan keterampilan menulis tidak hanya diperlukan pada saat seseorang masih bersekolah, bahkan setelah lulus pun seseorang perlu memiliki keterampilan menulis. Pada kurikulum 2013 terdapat kompetensi dasar yang mempelajari cerita inspiratif. Trianto, dkk (2018: 148) Cerita inspiratif merupakan bentuk narasi yang lebih bertujuan memberi inspirasi kebaikan kepada banyak orang. Cerita yang baik dapat menggugah perasaan, memberi kesan yang mendalam bahkan dalam tingkat yang lebih tinggi mampu membuat seseorang berjanji pada dirinya untuk menjadi seperti yang dibacanya, cerita yang menginspirasi seseorang berbuat lebih baik, lebih peduli, dan lebih berempati terhadap orang lain. Menurut Setiyaningsih dan Meita (2019: 135) adapun struktur dalam cerita inspiratif, yaitu orientasi, komplikasi, resolusi, dan koda.

KD 3.11 yang berisi mengidentifikasi isi ungkapan simpati, kepedulian, empati, atau perasaan pribadi dari teks cerita inspiratif yang dibaca dan didengar, 4.11 berisi menyimpulkan isi ungkapan simpati, kepedulian, empati atau perasaan pribadi dalam bentuk cerita inspiratifyang dibaca 
dan didengar, 3.12 berisimenelaah struktur, kebahasaan, dan isi teks cerita inspiratif, 4.12 berisi mengungkapkan rasa simpati, empati, kepedulian, dan perasaan dalam bentuk cerita inspiratif dengan memperbatikan struktur dan aspek kebahasaan.

Kegiatan menulis cerita inspiratif dapat menngingat pristiwa yang memberi motivasi, kepedulian, empati kepada pembacanya, karena setiap orang pasti memiliki kisah atau kejadian yang berbeda, sehingga dapat menginspirasi banyak orang, dalam kegiatan pembelajaran banyak media yang dapat digunakan untuk memperlancar dan mempermudah siswa dalam menerima pembelajaran yang diberikan, salah satunya dengan media berbasis visual. MenurutArsyad (2014: 89) media berbasis visual (image atau perumpamaan) memegang peran yang sangat penting dalam proses belajar. Media visual dapat memperlancar pemahaman (misalnya melalui elaborasi struktur dan organisasi) dan memperkuat ingatan. Visual dapat pula menumbuhkan minat siswa dan dapat memberikan hubungan antara isi materi pelajaran dengan dunia nyata. Agar menjadi efektif, visual sebaiknya ditempatkan pada konteks yang bermakna dan siswa harus berinteraksi dengan visual (image) itu untuk meyakinkan terjadinya proses informasi. Oleh karena itu dalam penelitian ini, peneliti menggunakan media visual dengan tema "Bersyukur" yang digunakan siswa untuk mengingat kembali cerita, pristiwa, bahkan pengalaman yang pernah terjadi melalui media visual berupa gambar atau vidio yang dikirimkan melalui Whatsapp dan kemudian menuangkan ide serta gagasannya kedalam bentuk tulisan, karena dalam keadaan Covid-19, maka peneliti dalam hal ini mengambil data mengenai kemampuan menulis cerita inspiratif tersebut dengan cara online.

Berdasarkan latar belakang tersebut, dan dilihat dari hasil tanya jawab dengan guru mata pelajaran bahasa, banyak siswa yang kurang termotivasi dalam menulis suatu karangan, padahal guru sudah menerapkan media pembelajaran yang cukup menarik untuk merangsang siswa dalam menulis cerita inspiratif dan juga cerita inspiratif diterapkan sejak sekolah dasar untuk menumbuhkan rasa empati dan simpati kepada lingkungan sekitar. Dilihat juga dari sistem zonasi dan latar belakang keluarga siswa yang berbeda. Jadi, peneliti ingin melakukan penelitian tentang kemampuan siswa kelas IX SMP Negeri 4 Kota Bengkulu dalam menuliskan cerita inspiratif berbentuk narasi berdasarkan gambar atau video yang akan dikirimkan melalui Whatsapp, sehingga dapat mengembangkan ide-ide nya berdasarkan gambar yang telah dilihat tersebut.

\section{METODE}

Penelitian ini menggunakan pendekatan kuantitatif dengan metode deskriptif yaitu apa adanya sesuai dengan fakta yang ada mengenai kemampuan menulis cerita inspiratif yang dibuat oleh peserta didik.

Penelitian ini dilakukan di SMP Negeri 4 Kota Bengkulu Kota. Waktu penelitian ini dilakukan pada semester genap tahun ajaran 2019/2020. Adapun teknik pengambilan sampel pada penelitian ini menggunakan teknik sampel random sampling. Peneliti mengambil sampel sebanyak 50 sampel dari jumlah populasi yang ada.

Teknik pengumpulan data dalam penelitian ini menggunakan teknik tes yang dilakukan peneliti melalui grup Whatsaap. Bentuk tes yang digunakan dalam penelitian ini berupa skor hasil belajar yang menggambarkan kemampuan siswa dalam menulis cerita inspiratif. Peneliti menuliskan seluruh nama siswa kelas IX SMP Negeri 4 Kota Bengkulu untuk diambil sampelnya sebanyak 50 siswa, kemudian sampel yang terpilih dimasukan 
ke grup Whatsaap dan siswa diminta menulis cerita inspiratif berdasarkan media visual yang telah dikirimkan melalui grup Whatsapp dengan tema "Bersyukur".

Dalam penelitian ini untuk mengetahui kemampuan menulis cerita inspiratif dengan media visual pada siswa SMP Negeri 4 Kota Bengkulu, yaitu berupa tugas membuat cerita inspiratif. Untuk memberikan nilai hasil kemampuan menulis cerita inspiratif terlebih dahulu diketahui skor atau bobot penilaian pada masing-masing aspek yang akan dinilai.

Setelah data penelitian terkumpul maka, untuk mengetahui gambaran tersebut diambil langkah-langkah sebagai berikut:

1. Membaca cerita inspiratif yang telah dibuat siswa kelas IX SMP Negeri 4 Kota Bengkulu berdasarkan media visual dengan tema "Bersyukur" secara keseluruhan.

2. Memeriksa hasil menulis cerita inspiratif siswa yang meliputi komponen isi, kelengkapan struktur, penggunaan diksi, kalimat, serta ejaan.

3. Memberikan skor pada aspek yang diperiksa sesuai dengan rubrik penilaian yang telah disiapkan.

4. Menyajikan data penilaian yang diperoleh siswa untuk setiap aspek penilaian yang diteliti.

5. Menghitung nilai rata-rata (mean) kemampuan menulis cerita inspiratif berdasarkan media visual dengan tema "Bersyukur".

Untuk mengetahui persentase kemampuan siswa dalam menulis cerita inspiratif, dapat digunakan rumus rata-rata (mean) sebagai berikut:

$\mathrm{M}=\frac{\sum X}{N}$

Keterangan:

$\mathrm{M} \quad=$ Mean (nilai rata-rata)

$\sum X \quad=$ Jumlah nilai secara keseluruhan

$\mathrm{N} \quad=$ Jumlah siswa

Table 1. Klasifikasi Kemampuan Menulis Cerita Inspiratif

\begin{tabular}{|c|c|c|}
\hline No & $\begin{array}{c}\text { Presentasi Tingkat } \\
\text { Penguasaan }\end{array}$ & Keterangan \\
\hline 1. & $86-100$ & Sangat Baik \\
\hline 2. & $76-85$ & Baik \\
\hline 3. & $60-75$ & Cukup \\
\hline 4. & $55-59$ & Kurang \\
\hline 5. & $1-54$ & Sangat Kurang \\
\hline \multicolumn{2}{|c|}{ Sumber: (Purwanto ,1984:103). }
\end{tabular}

\section{HASIL DAN PEMBAHASAN}

Hasil

Hasil penelitian ini merupakan data kemampuan menulis cerita inspiratif berdasarkan media visual siswa kelas IX SMP Negeri 4 Kota Bengkulu yang dilihat dari beberapa aspek yaitu:

1. Kemampuan menulis puisi siswa pada aspek kesesuaian isi dengan tema.

2. Kemampuan menulis puisi siswa pada aspek struktur. 
3. Kemampuan menulis puisi siswa pada aspek penggunaan diksi.

4. Kemampuan menulis puisi siswa pada aspek kalimat.

5. Kemampuan menulis puisi siswa pada aspek ejaan.

Hasil perhitungan di atas diperoleh dari nilai rata-rata kemampuan menulis cerita inspiratif berdasarkan media visual siswa yaitu 61,62 dengan kategori cukup. Maka hasil rata-rata pada setiap aspek yang diperoleh oleh sisiwa dapat dilihat dari tabel berikut:

Tabel Kemampuan Menulis menulis cerita inspiratif berdasarkan media visual siswa kelas IX SMP Negeri 4 Kota Bengkulu

\begin{tabular}{|l|l|c|c|}
\hline No & \multicolumn{1}{|c|}{ Aspek yang Dilihat } & $\begin{array}{c}\text { Rata-rata } \\
\text { Nilai }\end{array}$ & Kategori \\
\hline 1 & $\begin{array}{l}\text { Kesesuaian Isi dengan } \\
\text { tema }\end{array}$ & 17,07 & Baik \\
\hline 2 & Struktur & 27,37 & Sangat Baik \\
\hline 3 & Penggunaan Diksi & 8,17 & Kurang \\
\hline 4 & Penggunaan kalimat & 12,26 & Cukup \\
\hline 5 & Penggunaan ejaan & 6,23 & Cukup \\
\hline \multicolumn{2}{|c|}{ Rata-rata } & 61,62 & Cukup \\
\hline
\end{tabular}

Berdasarkan tabel di atas dapat diperoleh nilai rata-rata kemampuan menulis cerita inspiratif berdasarkan media visual siswa kelas IX SMP Negeri 4 Kota Bengkulu dengan nilai 61,62. Nilai tersebut apabila dilihat dari kriteria penilaian termasuk dalam kategori cukup. Artinya menunjukkan bahwa siswa belum baik dalam menulis cerita inspiratif berdasarkan media visual dari beberapa aspek, siswa masih belum sepenuhnya memahami dalam menulis cerita inspiratif.Karya yang ditulis siswa masih banyak menggunakan pilihan kata yang biasa saja, penggunaan diksi yang belum Nampak pada karya siswa, serta ejaan yang masih kurang baik.

Hasil perhitungan kemampuan menulis cerita inspiratif siswa kelas IX SMP Negeri 4 Kota Bengkulu jika dimasukkan dalam interval skala lima untuk perhitungan skor adalah sebagai berikut:

Table Tingkat Penguasaan Kemampuan Menulis Cerita Inspiratif Berdasarkan Media Visual Siswa Kelas IX SMP Negeri 4 Kota Bengkulu

\begin{tabular}{|c|c|c|c|}
\hline No & $\begin{array}{c}\text { Persentase Tingkat } \\
\text { Penguasaan }\end{array}$ & $\begin{array}{c}\text { Frekuensi } \\
\text { siswa }\end{array}$ & Keterangan \\
\hline 1. & $86-100$ & 1 & Sangat Baik \\
\hline 2. & $76-85$ & 8 & Baik \\
\hline 3. & $60-75$ & 23 & Cukup \\
\hline 4. & $55-59$ & 9 & Kurang \\
\hline 5. & $1-54$ & 11 & Sangat Kurang \\
\hline
\end{tabular}

Berdasarkan tabel diatas, maka grafik yang terbentuk dari hasil kemampuan menulis cerita inspiratrif berdasarkan media visual siswa adalah sebagai berikut: 
Kemampuan Menulis Cerita Inspiratif Berdasarkan Media Visual Siswa Kelas IX...

Diagram 1. Kemampuan Menulis cerita inspiratif berdasarkan media visual siswa kelas IX SMP Negeri 4 Kota Bengkulu

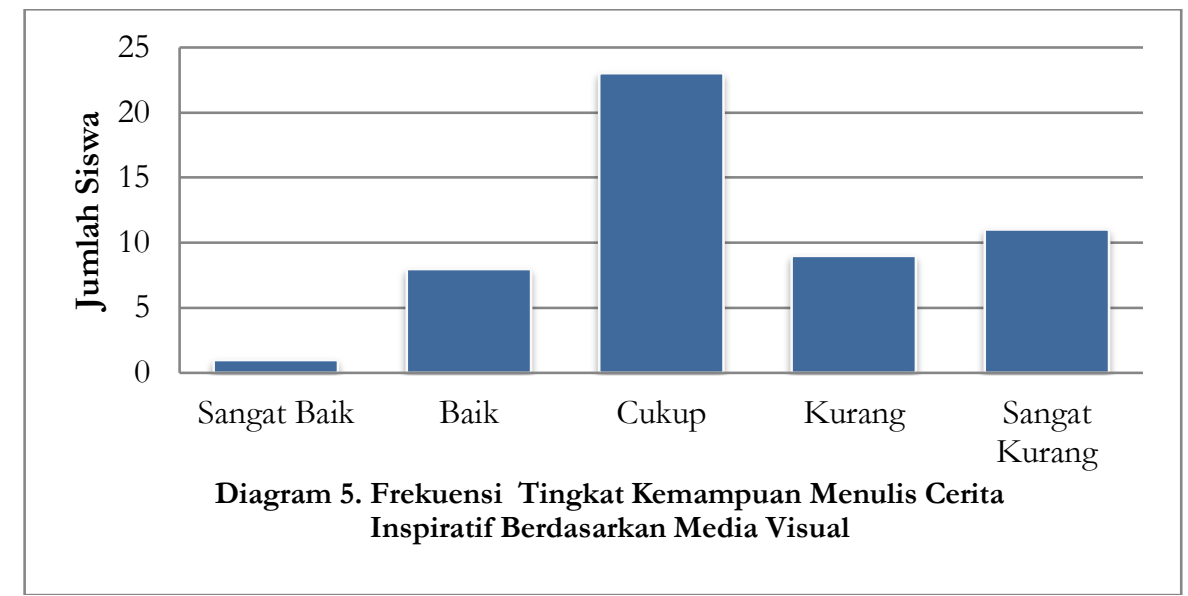

\section{Pembahasan}

Hasil penelitian kemampuan menulis cerita inspiratif berdasarkan media visual siswa kelas IX SMP Negeri 4 Kota Bengkulu mendapatkan nilai rata-rata sebesar 61,2 dengan kategori cukup, artinya siswa belum baik dalam kegiatan menulis cerita inspiratif yang dilihat dari beberapa aspek yaitu, kesesuaian antara isi dengan tema yang telah ditentukan, struktur yang ada dalam cerita inspiratif, penggunaan diksi yang dapat memotivasi pembacanya untuk melakukan sesuatu yang lebih baik atau menginspirasi, serta penggunaan kalimat dan ejaan yang baik dalam cerita inspiratif. Cerita inspiratif merupakan bentuk narasi yang lebih bertujuan memberi inspirasi kebaikan kepada banyak orang. Cerita yang baik dapat menggugah perasaan, memberi kesan yang mendalam bahkan dalam tingkat yang lebih tinggi mampu membuat seseorang berjanji pada dirinya untuk menjadi seperti yang dibacanya, cerita yang menginspirasi seseorang berbuat lebih baik, lebih peduli, dan lebih berempati terhadap orang lain melalui penggunaan diksi serta kalimat yang digunakan. Trianto, dkk (2018: 148)

Dilihat dari keseluruhan aspek menulis cerita inspiratif segi struktur, kesesuaian isi dengan tema, serta penggunaan kalimat hampir rata-rata siswa dapat menuliskannya dengan baik, tetapi dari aspek ejaan dan penggunaaan diksi siswa masih belum baik dan juga siswa dalam menuliskan cerita inspiratif masih kurang dalam memberi kesan yang mendalam serta menginspirasi pembacanya.

Selanjutnya, dari aspek kesesuaian isi dengan tema terdapat masalah atau gagasan yang akan digarap dalam suatu karangan, selain itu isi harus melukiskan terhadap masalah yang ditulis. Hasil kemampuan menulis cerita inspiratif dari aspek kesesuaian isi dengan tema yaitu dikategorikan sangat baik yaitu, cerita yang dibuat sesuai dengan tema yang telah ditentukan yaitu "Bersyukur", mencakup permasalahaan atau variable yang akan diuraikan, bersifat terbatas serta menarik. Hal tersebut sesuai dengan pendapat Pujiono, (2013: 2) topik merupakan masalah atau gagasan yang akan digarap dalam karangan, topik yang sudah menyempit dapat langsung dibuat judul, selain itu judul merupakan nama yang melukiskan dengan singkat maslah yang ditulis. Dari data tersebut dapat dilihat bawa siswa sudah mampu menuliskan suatu karangan dengan tema yang ditentukan 
yaitu"Bersyukur", walaupun ada beberapa siswa yang belum dapat menuliskan cerita inspiratifnya sesuai dengan tema yang ditentukan.

Kemudian, dalam aspek mengorganisasi struktur yang merupakan suatu keutuhan dalam cerita inspiratif yang meliputi, orientasi, komplikasi, resolusi, dan koda. Setiyaningsih dan Meita (2019: 135), dari aspek tersebut diperoleh nilai rata-rata 27,37 dengan kategori sangat baik, artinya kelengkapan dalam menuliskan struktur yang ada didalam cerita inspiratif hampir semua siswa sudah memenuhi kelengkapan struktur pembangun cerita inspiratif tersebut.

Dalam aspek penggunaan diksi dalam menyusun suatu wacana, dibutuhkan penggunaan kata yang tepat. Seorang penulis perlu menggunakan kata yang sesuai dengan jenis teks. Penggunaan yang tepat akan memudahkan penulis dalam mengungkapakan gagasan pokok. Cerita inspiratif cenderung mengungkapkan kisah yang memicu simpati, kepedulian, dan empati pembaca. Bahasa yang digunakan cerita inspiratif cenderung menyentuh hati pembaca. Maka dari itu, penulis cerita inspiratif perlu memilih kata dengan tepat, yakni dengan mempertimbangkan diksi. Diksi, dalam Kamus Besar Bahasa Indonesia, mempunyai arti pilihan kata yang tepat dan selaras untuk mengungkapkan gagasan sehingga diperoleh efek tertentu (seperti yang diharapkan). Untuk menulis cerita inspiratif, penulis dapat menggunakan pilihan kata kiasan. Kata kiasan merupakan kata yang tidak memiliki makna yang sebenarnya. Penggunaan diksi berupa kata-kata kiasan dapat memberikan kesan menarik dan menyentuh hati pembaca. Saaat menulis cerita inspiratif, kita bisa menggunakan diksi yang menarikdan dapat menyentuh pembaca. Setiyaningsih dan Meita (2019: 136).

Hasil dari aspek penggunaan diksi pada kalimat cerita inspiratif di ktegorikan kurang dengan nilai rata-rata 8,17, artinya hanya terdapat salah satu jenis diksi dalam karya yang ditulis siswa, karena masih siswa dalam menuliskan cerita inspiratifnya tidak terdapat penggunaan diksi, sedangkan agar cerita tersebut menjadi lebih menarik dan dapat memotivasi pembacanya diperlukan penggunaan diksi, seperti pemakaian kata bersinonim, pemakaian kata bermakna denotatif dan konotatif, pemakaian kata umum dan khusus, pemakaian kata- kata atau istilah asing, serta pemakaian kata popular dan kata kajian.

Walaupun penggunaan diksi masih kurang tetapi, penggunaan kalimatcerita inspiratif dikategori sangat baik, artinya siswa dalam menuliskan cerita inspiratifnya sudah memenuhi kalimat yang meliputi, kalimat tanya, kalimat perintah, dan kalimat berita. Seperti pendapat Setiyaningsih dan Meita (2019: 136) Cerita inspiratif disampaikan dalam kalimat-kalimat. Bermacam-macam kalimat muncul dalam cerita tersebut. Keberadaann kalimat-kalimat tersebut dipengaruhi oleh maksud yang ingin disampaikan penulis cerita yang meliputi kalimat Tanya, kalimat perintah, dan kalimat berita.

Sedangkan, dari analisis data kemampuan menulis cerita inspiratif dari aspek penilaian ejaaan dikategorikan cukup, karena dari hasil penelitian ini ada beberapa siswa yang sudah dapat menuliskan cerita inspiratifnya dengan penggunaan ejaan yang baik, tetapi masih ada beberapa siswa dalam penggunaan ejaannya masih salah atau tidak lengkap, baik itu tanda baca, penggunaaan huruf ataupun kataadapun penggunaan ejaan yang baik meliputi penulisan huruf, penulisan kata, dan penggunaan tanda baca. Hal tersebut sesuai dengan pendapat Putrayasa (2010: 21) ejaan adalah keseluruhan peraturan bagaimana melambangkan bunyi ujaran dan bagaimana hubungan antara tiap lambang 
atau bisa dikatakan pemisahan dan penggabungan dalam suatu bahasa, adapun ejaan dibagi menjadi penggunaan huruf, penggunaan tanda baca dan penggunaan kata.

Hasil tanya jawab dengan guru yang mengajar siswa kelas IX SMP Negeri 4 Kota Bengkulu, memang siswa dalam menulis suatu karangan dikategorikan cukup, dalam proses pembelajaranpunjuga sudah dilakukan dengan baik, seperti dengan menggunaakan media film, pengamatan keluar kelas agar sisawa tidak merasa jenuh dan lebih mudah dalam menuliskan narasinya kebentuk tulisan dan lainnya, tetapi ada juga beberapa siswa yangbelum dapat menuangkan ide serta gagasannya kedalam bentuk tulisan dengan baik serta menyambungkan antar paragraf. Menurut Suparno dan Yunus dalam Dalman (2016: 4) menulis merupakan suatu kegiatan penyampaian pesan (komunikasi) dengan menggunakan bahasa tulis sebagai alat atau medianya. Dalam penelitian ini siswa dalam menuliskan cerita inspiratif berdasarkan media visual yang sudah dilakukan melalui grup Whatsapp sudah dikategorikan cukup, mulai dari kesesuaian isi dengan tema, mengorganisasikan struktur yang meliputi orientasi, resolusi, komplikasi, koda, dan juga dalam penggunaan diksi, jenis kalimat, serta ejaan yang digunakan dalam karangan siswa.

\section{PENUTUP}

Berdasarkan hasil penelitian dan pembahasan Kemampuan Menulis Cerita Inspiratif Berdasarkan Media Visual Siswa Kelas IX SMP Negeri 4 Bengkulu secara umum dapat disimpulkan bahwa siswa mendapatkan kategori cukup, artinya siswa masih belum baik dan belum maksimal dalam kegiatan menulis cerita inspiratif berdasarkan media visual, sehingga siswa perlu mendalami lagi dalam kegiatan menulis suatu karangan khususnya cerita inspiratif.

Secara khusus kesimpulan hasil penelitian kemampuan menulis cerita inspiratif berdasarkan media visual dilihat dari aspek (1) kesesuaian isi dengan tema mendapatkan kategori sangat baik, yang meliputi kelengkapan cerita yang dibuat sesuai dengan tema yang telah, mencakup permasalahaan atau variable yang akan diuraikan, bersifat terbatas, menarik. (2) mengorganisasikan struktur cerita inspiratif yang dikategorikan sangat baik, yaitu terdapat semua struktur yang ada didalam cerita inspiratif meliputi, orientasi, komplikasi, resolusi, dan koda. (3) penggunaan diksi dalam cerita inspiratif dikategorikan cukup, artinya dalam menulis cerita inspiratif siswa masih belum baik, hanya terdapat beberapa jenis diksi yang ada didalam karangan yang ditulisnya. (4) penggunaan kalimat dalam cerita inspiratif dikategorikan cukup, artinya siswa belum baik dalam menuliskan ceritanya inspiratif yang tidak mencakup seluruh kalimat yang ada pada cerita inspiratif. (5) penggunaan ejaan dikategorikan cukup, artinya siswa belum baik dalam menuliskan suatu karanganny dengan penggunaan ejaan yang baik.

Hal tersebut menunjukan bahwa, siswa harus lebih memahami lagi dalam menulis suatu karangan terutama cerita inspiratif dan lebih memperhatikan kesesuaian isi dengan tema yang diberikan, pemilihan kosa kata serta tanda baca untuk meningkatkan kemampuan dalam menulis cerita inspiratif.

Berdasarkan hasil penelitian yang telah dilakukan, maka peneliti menyampaikan beberapa saran yang berkaitan dengan penelitian ini, yaitu:

1. Agar lebih banyak berlatih dalam menulis cerita, terutama cerita inspiratif dan lebih memperhatikan kesesuaian isi dengan tema yang diberikan, pemilihan kosa kata serta PUEBI dan tanda baca untuk meningkatkan kemampuan dalam menulis cerita inspiratif. 
Thossi Adios; Padi Utomo; Ria Ariesta

2. Meningkatkan mutu pembelajran di kelas khususnya dalam pembelajaran cerita inspiratif agar siswa lebih baik dalam menulis subuah karangan cerita.

\section{DAFTAR RUJUKAN}

Arsyad, Azhar. 2014. Media Pembelajaran. Jakarta: Rajawali Pers

Dalman. 2016. Keterampilan menulis. Jakarta: Rajawali Pers.

Purwanto, M. Ngalim. 1984. Prinsip-prinsip dan Teknik Evaluasi Pengajaran. Bandung: PT Remaja Rosdakarya.

Putrayasa, Ida. 2010. Kalimat Efektif. Bandung: Refika Aditama.

Trinto, Agus. Titik Harsiati. E. Kosasih. 2018. Bahasa Indonesia. Jakarta: Kementrian Pendidikan dan kebudayaan.

Setiyaningsih dan Meita. 2019. Bahasa Indonesia. Yogyakarta: PT Pariwara.

Wibowo. 2016. Prilaku Dalam Organisasi. Jakarta: Rajawali Pers. 